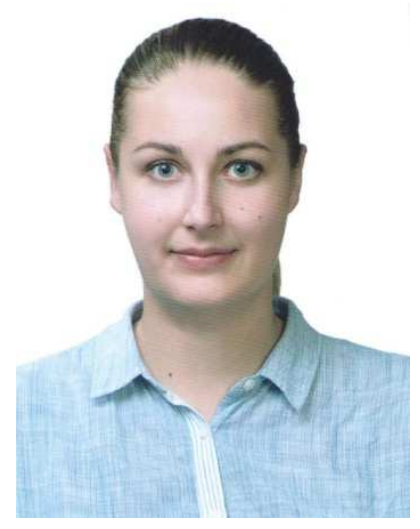

\author{
Катрич Анастасія В'ячеславівна, \\ кандидат юридичних наук \\ (Донечъкий державний університет \\ внутрішніх справ, м. Маріуполь) \\ ORCID: https://orcid.org/0000-0002-5011-4714
}

\title{
ВІДПОВІДАЛЬНІСТЬ ЗА ПОРУШЕННЯ ЗЕМЕЛЬНОГО ЗАКОНОДАВСТВА
}

Статтю присвячено визначенню понять «відповідалъністъ» та «юридична відповідальність за земелъні правопорушення». 3'ясовано, шо земелъне правопорушення - ие суспілъно икідлива винна дія чи бездіяльністъ, шо суперечить нормам земельного права. Земельні правопорушення розглядають як негативні сочіальні явища, оскільки вони посягають на земелъний лад $i$ правопорядок, спрямований забезпечувати рачіоналъне використання та охорону земель $i$ захист осіб, які використовують земельні ділянки. Зроблено висновок, шо юридична відповідальність застосовуєтъся за вчинення відповідного правопорушення: дисииплінарного або адміністративного проступку, кримінального злочину, иивілъно-правового порушення у сбері земелъних правовідносин.

Ключові слова: відповідалъністъ; юридична відповідалъністъ; юридичний бакт; земельне правопорушення.

Постановка проблеми. У статті 14 Конституції України встановлено, що землі $\epsilon$ основним національним багатством, яке перебуває під охороною держави. Це визначення $\epsilon$ основною умовою для зміцнення в Україні законності у сфері земельних відносин, а також удосконалення наявних засобів для іiі забезпечення. Земля - це елемент навколишнього природного середовища, що знаходиться в тісному взаємозв'язку з іншими його складовими (водними ресурсами, лісами, тваринним та рослинним світом), є головним фактором життєзабезпечення населення та засобом виробництва, необхідним для функціонування всіх галузей народного господарства. Одним із найважливіших засобів реалізації державної політики у сфері охорони земельних ресурсів є створення дієвої та ефективної нормативноправової бази, яка здатна забезпечити правопорядок у галузі земельних відносин.

Необхідним елементом правового забезпечення земельних відносин і захисту права на землю громадян, юридичних осіб, територіальних громад та держави, раціонального використання та охорони земель є застосування правових засобів впливу, спрямованих на усунення порушень земельного законодавства, відновлення порушеного права та притягнення винних у вчиненні земельних правопорушень до відповідальності. Нині за порушення земельного законодавства передбачається застосування дисциплінарної, цивільної, адміністративної та кримінальної відповідальності.

Аналіз останніх досліджень і публікацій. Питання відповідальності за порушення земельного законодавства досліджували такі вчені: Г. І. Балюк, О. В. Бєлікова, Н. В. Бондарчук, С. Л. Гоштинар, О. Ю. Дрозд, Д. М. Лук'янець, Л. В. Мілімко, О. С. Мірошниченко, О. В. Стукаленко, І. В. Федорчак, М. В. Шульга та ін., однак сучасний стан нормативно-правового забезпечення цього питання обумовлюють необхідність подальшого дослідження зазначеної проблематики.

Метою статті $\epsilon$ визначення понять «відповідальність» і «земельне правопорушення» та встановлення виду відповідальності за порушення земельного законодавства. 
Виклад основного матеріалу. Уперше термін «відповідальність» був уведений у науковий обіг Альфредом Беном, який трактував її як «покарання». У своїх наукових працях він визначав, що відповідальність - це негативний вплив на індивіда, що застосовується до суб'єкта, який порушив свої зобов'язання або здійснив правопорушення відповідних правових санкцій $[1$, с. 65]. В українських тлумачних словниках наведено приблизно однакове визначення поняття «відповідальність»: «покладений на когось або взятий на себе обов'язок відповідати за певну ділянку роботи, справу, за чиїсь дії, вчинки, слова» [2]. У словнику англійської мови це поняття тлумачиться як «стан буття людини, яка спричинила певну подію; обов'язок або завдання, яке особа повинна робити; те, що особа повинна зробити, тому що це морально правильно, вимагається за законом» [3].

Юридичну відповідальність традиційно розглядають як частину більш ширшого поняття - соціальна відповідальність. Поняття «соціальна відповідальність» $\epsilon$ методологічною основою виникнення поняття «юридична відповідальність» через аналіз співвідношення категорій свободи та необхідності. Відповідальність завжди пов'язана 3 необхідністю дотримання приписів, правил поведінки, підкорення, узгодження своїх учинків з об'єктивними законами природи та суспільства. Зокрема, якщо немає необхідності в дотриманні будь-яких норм, приписів, то немає й відповідальності [4, с. 8]. А. І. Андрющенко визначає, що соціальна відповідальність - це механізм взаємозалежності соціальних суб'єктів, що займають різні статусні позиції в соціальній ієрархії. У своїй роботі автор зауважує, що основою формування соціальної відповідальності є взаємодія інтересів соціальних суб'єктів, які можуть суперечити один одному [5, с. 133-135]. В. П. Моренець стверджує, що відповідальність - це загальносоціологічна категорія, яка виражає свідоме ставлення особи до суспільної необхідності, загальних потреб, обов'язків, норм, цінностей. Відповідальність означає усвідомлення суб'єктом суті та значення власної діяльності, іiі наслідків для суспільства, колективу, групи або кола осіб [6].

Відповідальність як окрема категорія розглядається і у філософії. 3 філософської точки зору можна сказати, що відповідальність сприймають як залежність від певних факторів і це є підставою для прийняття рішень суб'єктом [7, с. 55]. Українська дослідниця Ю. С. Осокіна визначає соціальну відповідальність у філософському сенсі як здатність соціального суб'єкта координувати у процесі спільної діяльності дії кожного з діями інших, усвідомлювати та належним чином коригувати наслідки своєї діяльності й бути готовим визнавати підзвітність своїх дій перед собою, співгромадянами та майбутніми поколіннями $[8$, c. 4$]$.

Відповідальність у психології розглядається як характеристика особистості. Специфіка психологічного аспекту відповідальності зумовлена поведінкою людини та пов'язана з їі почуттями та відчуттями. Категорія «відповідальність» знаходиться на одному рівні 3 категорією «особистість». «Відповідальність - здатність особистості розуміти відповідність результатів своїх дій поставленим цілям, визнаним у суспільстві або колективі нормам, у результаті чого виникає почуття співучасті у спільній справі, а в разі невідповідності - почуття невиконаного обов'язку; готовність індивіда визнати, що він сам $\epsilon$ причиною наслідків власної поведінки та діяльності» [9, с. 125].

Н. В. Іванчук указує, що відповідальність безпосередньо пов'язана 3 правами та обов'язками громадян, із виконанням взаємно прийнятих зобов'язань різними суб'єктами, із рівнем розвитку правосвідомості, правової культури громадян у суспільстві, тобто це «певна міра свободи» [10, с. 7].

На думку О. Ф. Скакун, «юридична відповідальність - це передбачені законом вид і міра державно-владного (примусового) зізнання особою втрат благ особистого, організаційного і майнового характеру за вчинене правопорушення» [11, с. 452].

На підставі аналізу різних підходів до тлумачення поняття «відповідальність» можна сформулювати загальне визначення: відповідальність - це: 1) вид державного примусу; 2) обов'язок порушника зазнати негативних наслідків учиненого ним правопорушення; 3) специфічні правові відносини; 4) покарання за правопорушення [12, с. 302]. 
Також потрібно визначити інститут юридичної відповідальності. Його доцільно зарахувати до фундаментальних інститутів сучасної системи права, оскільки він регулює усі сфери суспільного життя. Самостійна правова держава не може функціонувати без цього інституту. Сукупність норм юридичної відповідальності є своєрідним захисним механізмом для всієї системи права.

Інститут юридичної відповідальності характеризується такими ознаками: системністю і відносною відособленістю; імперативним методом як основним, а також диспозитивним і заохочувальним як додатковими; до факту вчинення правопорушення предметом його регулювання $\epsilon$ найбільш важливі суспільні відносини, а в разі вчинення правопорушення предметом його регулювання $\epsilon$ (переважно) матеріальні відносини відповідальності; $\epsilon$ публічним інститутом права; має складну структуру; виконує регулятивну, превентивну, каральну, відновлювальну й виховну функції; йому притаманні складні внутрішні та зовнішні взаємозв'язки координації та субординації.

Теоретичні аспекти юридичної відповідальності в земельному праві неодноразово досліджувалися в монографіях, наукових статтях, дисертаційних роботах як у радянський, так і в сучасний період. Їм приділено увагу також у підручниках та навчальних посібниках із земельного права.

Юридична відповідальність за земельні правопорушення в сучасній земельноправовій літературі визначається як особливий вид правовідношення охоронювального типу, що виникає внаслідок поєднання правової норми про юридичну відповідальність із земельним правопорушенням як юридичним фактом, у якому реалізується право держави захистити відповідні цінності, на які посягає земельне правопорушення, відновити порушене право або вимагати відшкодування шкоди, тобто покарати винну особу, а правопорушника зобов'язати зазнати певних позбавлень особистого, майнового чи організаційного характеру. Автори науково-практичного коментаря до Земельного кодексу України (далі - ЗК України) А. М. Мірошниченко та Р. І. Марусенко слушно зауважують, що юридичну відповідальність можна визначати як правовідносини із примусового покладення на правопорушника додаткових обов'язків негативного характеру або позбавлення його прав у зв'язку 3 учиненням правопорушення [13, с. 302].

Особливість юридичної відповідальності в земельному праві України полягає насамперед у тому, що в ЗК України використовується дуалістичний підхід до визначення іiі юридичної природи. По-перше, ЗК України розглядає їі як гарантію захисту права власності на землю. Так, у ст. 154, ст. 155 ЗК України встановлено відповідальність органів виконавчої влади та органів місцевого самоврядування за порушення права власності на землю та за видання актів, які порушують права власників земельних ділянок [14]. По-друге, юридичною відповідальністю одночасно $\epsilon$ самостійний правовий засіб примусового застосування відповідних заходів державного впливу щодо осіб, які порушують вимоги земельного законодавства. Також до специфічних рис, які характеризують цю відповідальність, слід віднести бланкетність правових приписів, що становлять правовий інститут юридичної відповідальності в земельному праві, та недостатній рівень систематизації правових норм, які регулюють відносини у сфері юридичної відповідальності за земельні правопорушення.

Відповідальність за порушення земельного законодавства завжди пов'язана 3 негативними правовими наслідками як результатом неправомірних діянь (дій чи бездіяльності) винної особи. У тих випадках, коли, наприклад, під час вилучення (викупу) земельних ділянок для державних або суспільних потреб власникам земельних ділянок або землекористувачам завдаються збитки, питання про відповідальність не виникає [15, с. 97]. У цьому разі йдеться про гарантії захисту порушених прав суб'єктів правомірними діями уповноважених державних органів.

Неправомірна поведінка можлива як з боку самих носіїв земельних прав, так і з боку сторонніх осіб. У зв'язку з цим серед негативних правових наслідків особливе місце займає примусове припинення земельних прав суб'єктів (право власності на земельну ділянку та право на землекористування), яке іноді називають земельно-правовою відповідальністю. 
Крім того, до винних осіб, які вчинили земельне правопорушення, можуть бути застосовані заходи адміністративного, дисциплінарного чи кримінального впливу, а за наявності заподіяної шкоди - iї відшкодування.

Відповідальність за порушення земельного законодавства виконує низку функцій: 1) вона $\epsilon$ засобом забезпечення виконання вимог земельного законодавства; 2) відповідальність у зазначеній сфері $є$ важливим елементом механізму гарантій земельних прав суб'єктів; 3) норми інституту юридичної відповідальності стимулюють додержання принципів земельного законодавства; 4) в умовах переходу економіки країни до ринкових відносин зростає роль компенсаційної функції юридичної відповідальності.

У правовій літературі іноді обгрунтовується необхідність виокремлення 3-поміж традиційних видів відповідальності саме спеціальної відповідальності за порушення земельного законодавства. Спеціальною вважається відповідальність, яку становлять заходи правового впливу на порушників земельного законодавства, передбачені ЗК України та законодавством, що його доповнює. Так, до спеціальної земельно-правової відповідальності в зазначеній сфері належить примусове припинення права користування земельною ділянкою, обов'язок знести власником земельної ділянки чи землекористувачем самовільно зведений об’єкт чи повернути самовільно зайняту ділянку тощо. Така точка зору $є$ дискусійною. Заходи впливу на правопорушників, які самовільно зайняли земельну ділянку або вчинили інше порушення, дійсно передбачені чинним законодавством. Але за своєю суттю вони є специфічними санкціями, які в адміністративному порядку застосовують судові та інші органи до правопорушників. Ці санкції можуть стосуватися як носіїв земельних прав, так й інших осіб-правопорушників. Уведення в обіг, окрім традиційних видів відповідальності, інших їі видів навряд чи є доцільним [16, с. 197].

Слід акцентувати увагу на тому, що юридична відповідальність за порушення земельного законодавства, поділяючись на різні види, може наставати як для фізичних, так i для юридичних осіб. До того ж необхідно пам'ятати, що кримінальна відповідальність в Україні - це персоніфікований вид юридичної відповідальності, а тому вона настає лише для конкретних фізичних осіб у разі вчинення ними злочину. Адміністративна та цивільноправова відповідальність за порушення норм земельного права може наставати i для юридичних осіб.

Отже, будь-який вид юридичної відповідальності застосовується за вчинення відповідного правопорушення: дисциплінарного або адміністративного проступку, кримінального злочину, цивільно-правового порушення.

Земельне правопорушення - це суспільно шкідлива винна дія чи бездіяльність, що суперечить нормам земельного права. Земельні правопорушення розглядають як негативні соціальні явища, оскільки вони посягають на земельний лад і правопорядок, спрямований забезпечувати раціональне використання та охорону земель і захист осіб, які використовують земельні ділянки.

Змістом земельних правопорушень є дії (чи бездіяльність), що суперечать вимогам норм земельного права. У земельному праві немає правових санкцій, розрахованих на всебічний вплив на суб'єктів земельних правопорушень. Тому для боротьби з ними застосовуються санкції різних галузей права [16, с. 207].

Юридична відповідальність може настати лише за наявності певного юридичного факту - факту вчинення правопорушення, що $є$ єдиною підставою для юридичної відповідальності.

У ст. 211 ЗК України закріплено перелік видів порушень земельного законодавства. До них належать: укладання угод 3 порушенням земельного законодавства; самовільне зайняття земельних ділянок; псування сільськогосподарських угідь та інших земель, забруднювання їх хімічними та радіоактивними речовинами і стічними водами, засмічування промисловими, побутовими та іншими відходами; розміщення, проєктування, будівництво, уведення в дію об'єктів, що негативно впливають на стан земель; невиконання вимог щодо використання земель за їх цільовим призначенням; порушення строків повернення 
тимчасово займаних земель або невиконання обов'язків щодо приведення їх у стан, придатний для використання за призначенням; знищення межових знаків; приховування від обліку і реєстрації та перекручування даних про стан земель, розміри та кількість земельних ділянок; непроведення рекультивації порушених земель; знищення або пошкодження протиерозійних і гідротехнічних споруд, захисних насаджень; невиконання умов знімання, збереження i нанесення родючого шару грунту; самовільне відхилення від проєктів землеустрою; ухилення від державної реєстрації земельних ділянок та подання недостовірної інформації щодо них; порушення строків розгляду заяв щодо відведення земельних ділянок [14].

Цей перелік не є вичерпним. Законодавством України можуть бути встановлені й інші види правопорушень, зокрема такі, як придбання земельних ділянок завдяки доходам, одержаним від злочинної діяльності.

Також залежно від конкретного виду об'єктів земельні правопорушення можна поділити на дві групи: власне земельні правопорушення та земельні правопорушення екологічної спрямованості.

Правопорушення першої групи порушують вимоги раціонального використання та охорони земель, законних прав та інтересів власників земельних ділянок i землекористувачів, у тому числі й орендарів. До них належать: невиконання вимог щодо використання земель за цільовим призначенням; самовільне зайняття земельних ділянок; знищення межових знаків; ухилення від державної реєстрації земельних ділянок і подання недостовірної інформації щодо них та деякі інші.

Серед цих правопорушень можна виокремити земельні правопорушення майнового характеру (наприклад, самовільне зайняття земельних ділянок) та земельні правопорушення у сфері управління (наприклад, приховування від обліку і реєстрації та перекручення даних про стан земель, розміри та кількість земельних ділянок).

До земельних правопорушень екологічної спрямованості належать порушення земельного законодавства, учинення яких пов'язане із заподіянням шкоди землі. Вони $\epsilon$ водночас й екологічними правопорушеннями, їх об'єкт - земля як невід'ємний елемент екосистеми. Цими правопорушеннями є: псування сільськогосподарських угідь та інших земель, їх забруднювання хімічними та радіоактивними речовинами і стічними водами, засмічування промисловими, побутовими та іншими відходами; невиконання умов знімання, збереження і нанесення родючого шару грунту та ін.

Поділ порушень земельного законодавства можливий і за іншими ознаками. Так, ураховуючи ступінь суспільної шкоди, серед земельних правопорушень розрізняють злочини i проступки. До злочинів належать суспільно небезпечні діяння, за вчинення яких передбачено кримінальну відповідальність. Серед них: забруднення або псування земель (ст. 239 Кримінального кодексу України); безгосподарне використання земель (ст. 254 Кримінального кодексу України); порушення правил екологічної безпеки (ст. 236 Кримінального кодексу України) тощо.

Усі інші неправомірні дії (крім злочинів), які порушують земельний правопорядок, кваліфікують як проступки, які, у свою чергу, за галузевою належністю поділяються на: дисциплінарні, адміністративні та цивільно-правові.

Висновки та перспективи подальших досліджень. Будь-який вид юридичної відповідальності застосовується за вчинення відповідного правопорушення: дисциплінарного або адміністративного проступку, кримінального злочину, цивільноправового порушення. У ст. 211 ЗК України закріплено перелік видів порушень земельного законодавства, який не $\epsilon$ вичерпним. Усе наведене свідчить про те, що земельне правопорушення - це винна, протиправна дія чи бездіяльність, що суперечить правовим нормам раціонального використання земельних ресурсів, перешкоджає здійсненню прав $\mathrm{i}$ законних інтересів власників землі та землекористувачів, порушує встановлений державою порядок управління земельним фондом як національним багатством нашої країни. Указано, що залежно від конкретного виду об'єктів земельні правопорушення можна поділити на дві групи: власне земельні правопорушення та земельні правопорушення екологічної 
спрямованості. Також визначено низку важливих функцій, які реалізуються під час притягнення до відповідальності за порушення земельного законодавства. Ці питання будуть актуальними для подальших досліджень.

\section{Список використаних джерел}

1. Йонас Г. Принцип ответственности. Опыт этики для технологической цивилизации (перевод с нем., предисловие, примечания И. И. Маханькова). М. : Айрис-пресс, 2004. 480 с.

2. Словник української мови : в 11 т. / за ред. І. К. Білодіда. К. : Наукова думка, 1970-1980. T. $1.1970 .805 \mathrm{c}$.

3. Merriam-Webster Dictionary. Online edition. URL: http://www.merriam-webster.com/ dictionary/responsibility (дата звернення: 28.06.2021).

4. Інститут юридичної відповідальності у демократичних правових системах : монографія / за заг. ред. Н. М. Оніщенко. К. : Видавництво «Юридична думка», 2009. 216 с.

5. Андрющенко А. І., Рябець І. М. Соціальна відповідальність: теоретико-методологічний аспект аналізу. Вісник Харківського національного університету ім. В. Н. Каразіна: Соціологічні дослідження сучасного суспільства. 2008. Вип. 23. С. 133-135.

6. Моренець В. П. Відповідальність як феномен. Оpen. Інтелект-проєкт Києво-Могилянської бізнес-школи. URL: http://open.kmbs.ua/vidpovidalnist-yak-fenomen/ (дата звернення: 28.06.2021).

7. Катрич А. В. Поняття відповідальності у господарському процесі: філософський аспект. Правова система України: сучасні тендениї та фактори розвитку : матеріали Міжн.-наук.-практ. конф. (Запоріжжя, 23-24 березня 2018 року), Запоріжжя : Запорізька міська громадська організація «Істина». С. 38-55.

8. Осокіна Ю. С. Відповідальність соціального суб'єкта: філософський аналіз : автореф. дис. ... канд. філософ. наук : 09.00.03. Київ. нац. ун-т ім. Т. Шевченка. К., 2007. 17 с.

9. Приходько Ю. О., Юрченко В. І. Психологічний словник-довідник : навч. посіб. К. : Каравела, 2012. 328 с.

10. Іванчук Н. В. Взаємна відповідальність особи і держави в контексті розбудови сучасної української держави : автореф. дис. ... канд. юрид. наук : 12.00.01. Київ. нац. ун-т внутр. справ. К., 2007. 19 с.

11. Скакун О. Ф. Теорія держави і права. Х. : Консум, 2001. 656 с.

12. Відповідальність у праві: філософія, історія, теорія : монографія / за заг. ред. І. Безклубого. К. : Грамота, 2014. 448 с.

13. Мірошниченко А. М. Земельне право України : навч. посіб. К. : Алерта, ЦУЛ, 2011. 678 с.

14. Земельний кодекс України : Закон України від 25 жовтня 2001 р. Відомості Верховної Ради України. URL: https://zakon.rada.gov.ua/laws/show/2768-14\#Text (дата звернення: 28.06.2021).

15. Килимник I. I., Міхно О. I. Земельне право України : навч. посіб. Х. : ХНУМГ ім. О. Бекетова, 2015. 166 с.

16. Шульга М. В. Земельне право України : підручник. / М. В. Шульга, Г. В. Анісімов, Н. О. Багай, А. П. Гетьман. К. : Юрінком Інтер, 2004. 368 с.

\section{References}

1. Jonas, G. (2004). Princip otvetstvennosti. Opyt etiki dlya tekhnologicheskoj civilizacii [Principle of responsibility. Ethics experience for technological civilization] (perevod s nem., predislovie, primechaniya I. I. Mahan'kova). M. : Ajris-press. 480 s. [in Russian].

2. Slovnyk ukrainskoi movy : v 11 t. [Ukrainian Dictionary: In 11 volumes] / za red. I. K. Bilodida. K. : Naukova dumka, 1970-1980. T. 1. 1970. 805 s. [in Ukrainian].

3. Merriam-Webster Dictionary. Online edition. URL: http://www.merriam-webster.com/ dictionary/responsibility (data zvernennia: 28.06.2021).

4. Instytut yurydychnoi vidpovidalnosti u demokratychnykh pravovykh systemakh [Institute of Legal Liability in Democratic Legal Systems]: monohrafiia/ za zah. red. N. M. Onishchenko. K. : Vydavnytstvo «Iurydychna dumka», 2009. 216 s. [in Ukrainian].

5. Andriushchenko, A. I., Riabets, I. M. (2008). Sotsialna vidpovidalnist: teoretykometodolohichnyi aspekt analizu [Social Responsibility: Theoretical and Methodological Aspect of Analysis]. Visnyk Kharkivskoho natsionalnoho universytetu im. V. N. Karazina: Sotsiolohichni doslidzhennia suchasnoho suspilstva. Vyp. 23. S. 133-135 [in Ukrainian].

6. Morenets, V. P. Vidpovidalnist yak fenomen [Responsibility as phenomenon]. Open. Intelektproiekt Kyievo-Mohylianskoi biznes-shkoly. URL: http://open.kmbs.ua/vidpovidalnist-yak-fenomen/ (data zvernennia: 28.06.2021) [in Ukrainian]. 
7. Katrych, A. V. (2018). Poniattia vidpovidalnosti u hospodarskomu protsesi: filosofskyi aspekt [The notion of responsibility in the economic process: the philosophical aspect]. Pravova systema Ukrainy: suchasni tendentsii ta faktory rozvytku: materialy Mizhn.-nauk.-prakt. konf. (Zaporizhzhia, 23-24 bereznia 2018 roku), Zaporizhzhia: Zaporizka miska hromadska orhanizatsiia «Istyna». S. 38-55 [in Ukrainian].

8. Osokina, Yu. S. (2007). Vidpovidalnist sotsialnoho subiekta: filosofskyi analiz [Responsibility of the Social Subject: Philosophical Analysis] : avtoref. dys. ... kand. filosof. nauk : 09.00.03. Kyiv. nats. un-t im. T. Shevchenka. K. 17 s. [in Ukrainian].

9. Prykhodko, Yu. O., Yurchenko, V. I. (2012). Psykholohichnyi slovnyk-dovidnyk [Psychological Dictionary-Directory] : navch. posib. K. : Karavela. 328 s. [in Ukrainian].

10. Ivanchuk, N. V. (2007). Vzaiemna vidpovidalnist osoby i derzhavy v konteksti rozbudovy suchasnoi ukrainskoi derzhavy [Mutual responsibility of the person and state in the context of building a modern Ukrainian state] : avtoref. dys. ... kand. yuryd. nauk : 12.00.01. Kyiv. nats. un-t vnutr. sprav. K. $19 \mathrm{~s}$. [in Ukrainian].

11. Skakun, O. F. (2001). Teoriia derzhavy i prava [Theory of state and law]. Kh. : Konsum. 656 s. [in Ukrainian].

12. Vidpovidalnist u pravi: filosofiia, istoriia, teoriia [Responsibility in Right: Philosophy, History, Theory] : monohrafiia / za zah. red. I. Bezkluboho. K. : Hramota, 2014. 448 s. [in Ukrainian].

13. Miroshnychenko, A. M. (2011). Zemelne pravo Ukrainy [Land Law of Ukraine] : navch. posib. K. : Alerta, TsUL. 678 s. [in Ukrainian].

14. Zemelnyi kodeks Ukrainy: Zakon Ukrainy vid 25 zhovtnia 2001 r. Vidomosti Verkhovnoi Rady Ukrainy. URL: https://zakon.rada.gov.ua/laws/show/2768-14\#Text (data zvernennia: 28.06.2021) [in Ukrainian].

15. Kylymnyk, I. I., Mikhno, O. I. (2015). Zemelne pravo Ukrainy [Land Law of Ukraine] : navch. posib. Kh. : KhNUMH im. O. Beketova. 166 s. [in Ukrainian].

16. Shulha, M. V. (2004). Zemelne pravo Ukrainy [Land Law of Ukraine] : pidruchnyk / M. V. Shulha, H. V. Anisimov, N. O. Bahai, A. P. Hetman. K. : Yurinkom Inter. 368 s. [in Ukrainian].

\author{
Katrych Anastasia, \\ $\mathrm{PhD}$ in Law \\ (Donetsk State University of Internal Affairs, Mariupol) \\ ORCID: $h$ ttps://orcid.org/0000-0002-5011-4714
}

\title{
RESPONSIBILITY FOR VIOLATION OF LAND LEGISLATION
}

The article is devoted to the theoretical definition of the concepts of responsibility, legal responsibility, land offense «responsibility" and «legal responsibility for land offenses». It has been established that a land offense is a socially harmful criminal act or omission that contradicts the norms of land law. Land offenses are considered as negative social phenomena, as they encroach on the land system and law and order, aimed at ensuring the rational use and protection of land and protection of persons using land. It is concluded that legal liability is applied for the commission of the relevant offense: disciplinary or administrative misconduct, criminal offense, civil violation in the field of land relations. All the above indicates that a land offense is a guilty, illegal act or omission that contradicts the legal norms of rational use of land resources, impedes the rights and legitimate interests of landowners and land users, violates the state procedure for land management as the national wealth of our country. It is stated that depending on the specific type of objects, land offenses can be divided into two groups: the actual land offenses and land offenses of environmental orientation. It also identifies a number of important functions that are implemented during prosecution for violations of land legislation. These questions will be relevant for further research. A land offense is a socially harmful criminal act or omission that contradicts the norms of land law. Land offenses are considered as negative social phenomena, as they encroach on the land system and law and order, aimed at ensuring the rational use and protection of land and protection of persons who use land. Also, depending on the specific type of objects, land offenses can be divided into two groups: the actual land offenses and land offenses of environmental orientation. Offenses of the first group violate the requirements of rational use and protection of land, legal rights and interests of landowners and land users, including tenants. These include: noncompliance with the requirements for the use of land for its intended purpose; unauthorized occupation of land plots; destruction of boundary markers; evasion of state registration of land plots and submission of unreliable information about them and some others.

Key words: responsibility; legal responsibility; legal fact; land offense.

Надіслано до редколегії 11.08.2021 Рекомендовано до публікації 17.08.2021 